\title{
Generation and Role of Oscillatory Contractions in Mouse Airway Smooth Muscle
}

\author{
Hao Xua Ping Zhao ${ }^{a}$ Wen-Jing Zhang ${ }^{a}$ Jun-Ying Qiu ${ }^{a} \quad$ Li Tan $^{a}$ \\ Xiao-Cao Liu ${ }^{a}$ Qian Wang ${ }^{a}$ Xi Luo ${ }^{a}$ Yu-Shan She ${ }^{a}$ Dun-An Zang ${ }^{a}$ \\ Bei-Bei Liu ${ }^{a}$ Lei Cao ${ }^{a} \quad$ Xiao-Xue Zhao ${ }^{a}$ Yuan-Yuan Chen ${ }^{a}$ Meng-Yue Lia \\ Jinhua Shen ${ }^{\mathrm{a}}$ Yong-Bo Peng ${ }^{\mathrm{a}} \quad$ Lu Xue $^{\mathrm{a}}$ Meng-Fei Yua Weiwei Chen ${ }^{\mathrm{a}}$ \\ Li-Qun Ma ${ }^{a}$ Gangjian Qin ${ }^{b}$ Qing-Hua Liu
}

anstitute for Medical Biology, College of Life Sciences, South-Central University for Nationalities,

Wuhan, China, ${ }^{b}$ Department of Biomedical Engineering, School of Medicine \& School of Engineering,

University of Alabama Birmingham, USA

\section{Key Words}

Oscillatory contractions $\cdot$ Airway smooth muscle $\cdot \mathrm{Ca}^{2+} \cdot$ Oscillations $\bullet$ Ion channels

\begin{abstract}
Background/Aims: Tetraethylammonium chloride (TEA) induces oscillatory contractions in mouse airway smooth muscle (ASM); however, the generation and maintenance of oscillatory contractions and their role in ASM are unclear. Methods: In this study, oscillations of ASM contraction and intracellular $\mathrm{Ca}^{2+}$ were measured using force measuring and $\mathrm{Ca}^{2+}$ imaging technique, respectively. TEA, nifedipine, niflumic acid, acetylcholine chloride, lithium chloride, KB-R7943, ouabain, 2-Aminoethoxydiphenyl borate, thapsigargin, tetrodotoxin, and ryanodine were used to assess the mechanism of oscillatory contractions. Results: TEA induced depolarization, resulting in activation of L-type voltage-dependent $\mathrm{Ca}^{2+}$ channels (LVDCCs) and voltage-dependent $\mathrm{Na}^{+}\left(\mathrm{V}_{\mathrm{Na}}\right)$ channels. The former mediated $\mathrm{Ca}^{2+}$ influx to trigger a contraction and the latter mediated $\mathrm{Na}^{+}$entry to enhance the contraction via activating LVDCCS. Meanwhile, increased $\mathrm{Ca}^{2+}$-activated $\mathrm{Cl}^{-}$channels, inducing depolarization that resulted in contraction through LVDCCs. In addition, the contraction was enhanced by intracellular $\mathrm{Ca}^{2+}$ release from $\mathrm{Ca}^{2+}$ stores mediated by inositol $(1,4,5)$-trisphosphate receptors ( $\left.\mathrm{IP}_{3} \mathrm{Rs}\right)$. These pathways together produce the contractile phase of the oscillatory contractions. Furthermore, the increased $\mathrm{Ca}^{2+}$ activated the $\mathrm{Na}^{+}-\mathrm{Ca}^{2+}$ exchanger (NCX), which transferred $\mathrm{Ca}^{2+}$ out of and $\mathrm{Na}^{+}$into the cells. The former induced relaxation and the latter activated $\mathrm{Na}^{+} / \mathrm{K}^{+}$-ATPase that induced hypopolarization to inactivate LVDCCs causing further relaxation. This can also explain the relaxant phase of the oscillatory contractions. Moreover, the depolarization induced by $\mathrm{V}_{\mathrm{Na}}$ channels and NCX might be greater than the hypopolarization caused by $\mathrm{Na}^{+} / \mathrm{K}^{+}$-ATPase
\end{abstract}

H. Xu, P. Zhao, W.-J. Zhang and J.-Y. Qiu contributed equally to this work.

Qing-Hua Liu, M.D., Ph.D.

Institute for Medical Biology, College of Life Sciences, South-Central University for Nationalities, 182 Min Zu Da Dao, Wuhan 430074, Hubei (China)

E-Mail qinghualiu@mail.scuec.edu.cn, liu258q@yahoo.com 
alone, inducing LVDCC activation and resulting in further contraction. Conclusions: These data indicate that the TEA-induced oscillatory contractions were cooperatively produced by LVDCCs, $V_{\mathrm{Na}}$ channels, $\mathrm{Ca}^{2+}$-activated $\mathrm{Cl}^{-}$channels, $\mathrm{NCX}, \mathrm{Na}^{+} / \mathrm{K}^{+}$ATPase, $\mathrm{IP}_{3} \mathrm{Rs}$-mediated $\mathrm{Ca}^{2+}$ release, and extracellular $\mathrm{Ca}^{2+}$.

(c) 2018 The Author(s)

Published by S. Karger AG, Basel

\section{Introduction}

Deep inspiration and tidal breathing in humans inhibit subsequent bronchocontraction (termed bronchoprotection), which is due to an increased muscle length due to stretching of the lung parenchyma $[1,2]$. The mechanism might be disruption of the cross-linking of actomyosin and other proteins such as zyxin; however, muscle stretch may have less or even reverse effects on the subsequent contraction in asthmatic airway smooth muscle (ASM) [39]. Consistent with these observations, oscillatory muscle stretch enhanced and attenuated electrical field stimulation-induced contraction in tracheal and bronchial ASM, respectively [10]. Thus, the effect of oscillatory contractions on the subsequent contraction of ASM is still unclear.

Oscillatory contractions in ASM can also spontaneously occur [11]; they were observed in cultured airways from human fetuses at $37^{\circ} \mathrm{C}$ but were reduceed as the temperature was lowered to $32^{\circ} \mathrm{C}$. Moreover, oscillatory contractions can be abolished by nitric oxide (NO)releasing drugs but are enhanced by carbachol [11]. Temperature decrease-induced abolition of oscillatory contractions has also been observed in precontracted canine ASM induced by cyclopiazonic acid (a selective blocker of the sarcoplasmic reticulum (SR) calcium-pump). This was because the $\mathrm{Na}^{+} / \mathrm{K}^{+}$ATPase was inhibited at low temperature, which resulted in a sustained increase in intracellular $\mathrm{Ca}^{2+}$ and then led to the disappearance of the oscillatory contraction $[12,13]$. The effect of NO-releasing drugs on the oscillatory contractions was due to the finding that the increased NO inhibited release of calcium through inositol (1, 4,5)-trisphosphate receptors ( $\mathrm{IP}_{3} \mathrm{Rs}$ ), leading to abolition of the contractions [14]. Carbachol is a known agonist of muscarinic (M) receptors and stimulates $M$ receptors to increase calcium. Therefore, the spontaneous oscillatory contractions would result from changes in intracellular $\mathrm{Ca}^{2+}$ concentration.

Oscillatory contractions can also be produced by agents such as the non-selective blocker of $\mathrm{K}^{+}$channels tetraethylammonium chloride (TEA) and $\mathrm{Ca}^{2+}$-activated $\mathrm{K}^{+}(\mathrm{Kca})$ channel blockers charybdotoxin and iberiotoxin [15-18]. On the other hand, the oscillatory contractions can be inhibited by the removal of external $\mathrm{Ca}^{2+}$ and by addition of $\mathrm{Ca}^{2+}$ channel blockers $[15,16,18]$ or a protein kinase C (PKC) inhibitor, but are enhanced by a PKC activator [18]. In addition, PKC can activate L-type voltage-dependent $\mathrm{Ca}^{2+}$ channels (LVDCCs) [19]. Therefore, oscillatory contractions would depend on cytosolic $\mathrm{Ca}^{2+}$ increases. Consistent with this, ryanodine (a selective blocker of ryanodine receptors, RyRs) and thapsigargin (TG, an inhibitor of the calcium-pump) can also inhibit the oscillatory contractions [18]. Furthermore, the oscillatory contractions were abolished by an inhibitor of prostaglandin $\mathrm{E}_{2}$ $\left(\mathrm{PGE}_{2}\right)$ receptor subtype EP1 [17], which mediated intracellular $\mathrm{Ca}^{2+}$ increases [20]. Overall, oscillatory contractions likely result from alternations of intracellular $\mathrm{Ca}^{2+}$ concentration.

Oscillations of cytosolic $\mathrm{Ca}^{2+}$ have been observed in ASM cells, induced by various agents such as acetylcholine (ACH), carbachol, methacholine, ATP, 5-hydroxytryptamine, leukotriene 4 , phorbol myristate acetate, and high $\mathrm{K}^{+}[14,21-34]$. $\mathrm{Ca}^{2+}$ concentration increased via release from the SR through $\mathrm{IP}_{3} \mathrm{Rs}[23,26,30,32]$ and RyRs $[30,31]$, as well as via influx through ion channels such as, LVDCCs [31, 33, 34] and store-operated $\mathrm{Ca}^{2+}$ entry [30, 33, 34]. Moreover, $\mathrm{Ca}^{2+}$ oscillations were regulated by many other factors such as $\mathrm{M}_{3}$ receptor [21], bitter taste receptor TAS2R10 [32], PLC [23], cAMP [26], and PI3K [28].

However, these $\mathrm{Ca}^{2+}$ oscillations resulted in a sustained contraction, not the abovementioned oscillatory contractions [14, 23, 25-28, 32, 33]. Why did the oscillatory contractions not occur? The reason could be that their frequency was too high. It has been reported that $\mathrm{ACH}$ induced electrical oscillatory waves in pig tracheal smooth muscle in the 


\section{Cellular Physiology Cell Physiol Biochem 2018;47:1546-1555

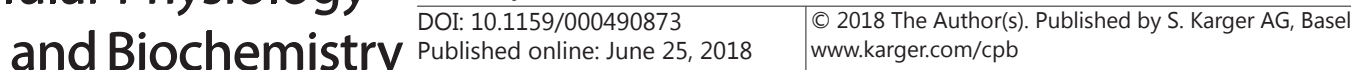 \\ Xu et al.: Oscillatory Contractions in Airway Smooth Muscle}

presence of TEA, which then resulted in rhythmic activation of LVDCCs, leading to $\mathrm{Ca}^{2+}$ influx to cause the oscillatory contractions. However, when the frequency of the electrical waves $>40 / \mathrm{min}$, the triggered oscillatory contractions would become a sustained contraction [16]. We estimated the frequencies of $\mathrm{Ca}^{2+}$ oscillations in these studies and found that they were $>40 / \mathrm{min}$. Thus, oscillatory contractions were not observed. Therefore, the mechanism underlying the oscillatory contractions remains unclear.

TEA can induce oscillatory contractions allowing us to investigate the underlying mechanism [15]. Thus, in this study, TEA was used to induce oscillatory contractions in mouse ASM and then investigated the mechanism. We found that the oscillatory contractions were cooperatively produced by LVDCCs, $\mathrm{V}_{\mathrm{Na}}$ channels, $\mathrm{Ca}^{2+}$-activated $\mathrm{Cl}^{-}$(Clca) channels, $\mathrm{Na}^{+}-\mathrm{Ca}^{2+}$ exchanger (NCX), $\mathrm{Na}^{+} / \mathrm{K}^{+}$ATPase, $\mathrm{IP}_{3} \mathrm{Rs} \mathrm{Ca}^{2+}$ pump, and external $\mathrm{Ca}^{2+}$.

\section{Materials and Methods}

\section{Reagents}

TEA, nifedipine, niflumic acid, ACH, lithium chloride, KB-R7943, ouabain, 2-Aminoethoxydiphenyl borate (2-APB), thapsigargin (TG), and bovine serum albumin (BSA) were purchased from Sigma (St. Louis, MO, USA). Ryanodine was purchased from Alomone Labs (Jerusalem, Israel), and tetrodotoxin (TTX) was purchased from Aladdin (Shanghai, China). Nifedipine, niflumic acid, 2-APB, TG, and ryanodine were dissolved in DMSO, TTX was dissolved in acetic acid, and all others were dissolved in the vehicle used in the experiments.

\section{Animals}

Six-week-old male BALB/c mice were purchased from the Hubei Provincial Center for Disease Control and Prevention (Wuhan, China) and were housed in a standard animal facility. Experiments were approved by the Institutional Animal Care and Use Committee of the South-Central University for Nationalities.

\section{Contraction measurements of ASM}

ASM contraction was measured in tracheal rings (TRs) as previously described [35-37]. In brief, after the mice were killed by an intraperitoneal injection of sodium pentobarbital $(150 \mathrm{mg} / \mathrm{kg})$ and then the tracheae were cut and placed in ice cold physiological salt solution (PSS) (mM): $\mathrm{NaCl} 135, \mathrm{KCl} 5, \mathrm{MgCl}_{2} 1$, $\mathrm{CaCl}_{2} 2$, HEPES 10 , and glucose $10(\mathrm{pH}=7.4)$. Distal TRs $(5 \mathrm{~mm})$ were cut and mounted in $10-\mathrm{mL}$ organ baths containing PSS bubbled with $95 \% \mathrm{O}_{2}$ and $5 \% \mathrm{CO}_{2}$ at $37^{\circ} \mathrm{C}$. The TRs with 0.3 g preload were equilibrated for $60 \mathrm{~min}$. Precontraction with $10^{-4} \mathrm{M} \mathrm{ACH}$ was was performed three times, and experiments were performed after $30 \mathrm{~min}$.

\section{Measurements of intracellular $\mathrm{Ca}^{2+}$}

Single mouse tracheal smooth muscle cells were isolated as previously described with some modifications [36, 38]. Briefly, mice were killed by intraperitoneal injection of sodium pentobarbital $(150 \mathrm{mg} / \mathrm{kg})$ and the tracheae were removed and transferred to ice-cold PSS containing $0.1 \mathrm{mM} \mathrm{CaCl}_{2}$. The trachealis tissues were isolated and minced and incubated for $22 \mathrm{~min}$ at $35^{\circ} \mathrm{C}$ in the above solution supplemented with $2 \mathrm{mg} / \mathrm{mL}$ papain, $1 \mathrm{mg} / \mathrm{mL}$ dithioerythritol, and $1 \mathrm{mg} / \mathrm{mL}$ BSA. The tissues were transferred to the above solution supplemented with $1 \mathrm{mg} / \mathrm{mL}$ collagenase $\mathrm{H}, 0.15 \mathrm{mg} / \mathrm{mL}$ dithiothreitol, and $1 \mathrm{mg} / \mathrm{mL}$ BSA and incubated for a further $8 \mathrm{~min}$. Then, the tissues were washed and gently triturated to release single smooth muscle cells.

Cells were loaded with $2 \mu \mathrm{M}$ fluo-4AM for $20 \mathrm{~min}$ and intracellular $\mathrm{Ca}^{2+}$ was measured and analyzed using an LSM 700 laser scanning confocal system and Zen 2010 software (Carl Zeiss, Jena, Germany) as previously described [35].

\section{Statistical Analysis}

The results are expressed as means \pm SEM, Student's $t$-test was used for comparisons, and the $\mathrm{P}<0.05$ was considered significant. 


\section{Results}

\section{TEA triggers oscillatory} contractions

TEA dose-dependently induced oscillatory contractions in quiescent mouse TRs (Fig. 1A). ASM has a tone in vivo, therefore, to mimic this tone in vitro, we precontracted TRs using a low concentration of $\mathrm{ACH}$ $(1 \mu \mathrm{M})$ and then observed the TEA-induced oscillatory contractions (Fig. 1B). We did not investigate the relaxation induced by 1 mM TEA in this study (Fig. 1B). The results, summarized in Fig. $1 \mathrm{C}$, show that TEA (from $10 \mu \mathrm{M}$ ) induced oscillatory contractions in ACH-precontracted TRs, but their frequency (at 20 and $30 \mu \mathrm{M}$ ) was lower and amplitude (at $30 \mu \mathrm{M}$ ) was larger compared with resting TRs.

\section{Mechanism of the oscil-} latory contractions

We then used $10 \mathrm{mM}$ TEA to induce the oscillatory contractions in $1 \mu \mathrm{M}$ ACH-precontracted TRs (Fig. 2, $\mathrm{n}=8$ ) and investigated the underlying mechanism. TEA is a non-selective blocker of $\mathrm{K}^{+}$channels. It can induce depolarization of approximately $28 \mathrm{mV}$ in human ASM cells [39]. This depolarization would activate LVDCCs and $\mathrm{V}_{\mathrm{Na}}$ channels expressed in ASMCs $[35,40]$, mediating $\mathrm{Ca}^{2+}$ and $\mathrm{Na}^{+}$influx. The former will induce cytosolic $\mathrm{Ca}^{2+}$ elevations, causing a contraction; the latter will lead to an additional depolarization to activate LVDCCs, resulting in further contraction. Thus, we investigated the effect of nifedipine (a selective blocker of LVDCCs) and TTX (a selective blocker of $\mathrm{V}_{\mathrm{Na}}$ channels) on the oscillatory contractions. The results show that both blockers inhibited the oscillatory contractions (Fig. 3, $\mathrm{n}=6$ TRs for both groups).

The increased $\mathrm{Ca}^{2+}$ will activate $\mathrm{Ca}^{2+}$-activated channels such as Clca and Kca channels. However, the latter would have been blocked by TEA. Thus, we blocked the former using niflumic acid, which abolished oscillatory contractions in the TRs (Fig. 4, $\mathrm{n}=6$ ). These data 
Fig. 3. LVDCCs and $\mathrm{V}_{\mathrm{Na}}$ channels play a role in TEA-induced oscillatory contractions. TEA-induced oscillatory contractions in a TR were blocked by LVDCC blocker nifedipine (A) and $\mathrm{V}_{\mathrm{Na}}$ channel blocker TTX (B).

suggest that Clca channels

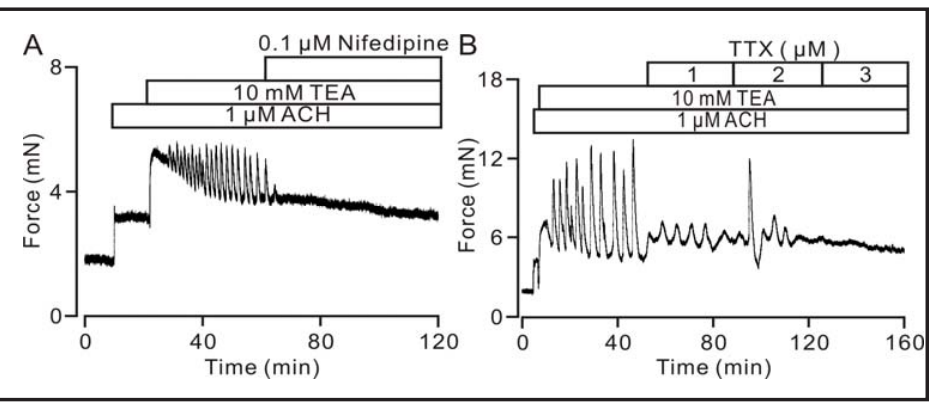
play a role in the oscillatory contractions.

The increased intracellular $\mathrm{Ca}^{2+}$ will also activate NCX expressed in ASM [41, 42]. We found that when NCX was inhibited by replacing $\mathrm{Na}^{+}$with $\mathrm{Li}^{+}$, the TEA-induced oscillatory contractions were transiently enhanced and then disappeared (Fig. 5A, $n$ $=6$ TRs). Moreover, the TEA-induced oscillatory contractions were also abolished by the selective NCX blocker KB-R7943 (Fig. $5 B, n=6$ TRs). These experiments reveal that the oscillatory contractions require NCX.

In addition, NCX will induce cytosolic $\mathrm{Na}^{+}$increases, which will then activate $\mathrm{Na}^{+} / \mathrm{K}^{+}$-ATPase $[42,43]$. Following the inhibition of this enzyme by ouabain, a larger contraction was observed and the oscillatory contractions then vanished (Fig. 6, $n$ $=6$ TRs). This suggests that $\mathrm{Na}^{+} / \mathrm{K}^{+}$-ATPase is essential for the occurrence of the oscillatory contractions.

The above results indicate that the oscillatory contractions likely result from oscillatory rises in intracellular $\mathrm{Ca}^{2+}$ concentration. To test this hypothesis, cytosolic $\mathrm{Ca}^{2+}$ was measured. The results show that TEA induced fast $\mathrm{Ca}^{2+}$ oscillations, as well as another relatively slow rhythmicity.. The frequency of the rhythmicity was 0.32 $\pm 0.05 / \mathrm{min}(\mathrm{n}=25)$ (Fig. 7A), which was lower than that of the oscillatory contractions induced by TEA $(0.55 \pm 0.05$ oscillation $/ \mathrm{min}, \mathrm{n}=38, \mathrm{P}<0.001)$. These results suggest that in addition to the lower rhythmicity, the larger, faster $\mathrm{Ca}^{2+}$ oscillations might also trigger a single contraction.

ACH causes $\mathrm{Ca}^{2+}$ release from intracellular $\mathrm{Ca}^{2+}$ store, which would affect the TEA-induced $\mathrm{Ca}^{2+}$ oscillations and contraction. TG, an inhibitor of the SR calcium pump, abolished the oscillatory contractions (Fig. 8A, $n=6$ TRs), which

Fig. 4. Niflumic acid inhibits oscillatory contractions. TE A - ind uced oscillatory contractions in a TR were inhibited by niflumic acid.

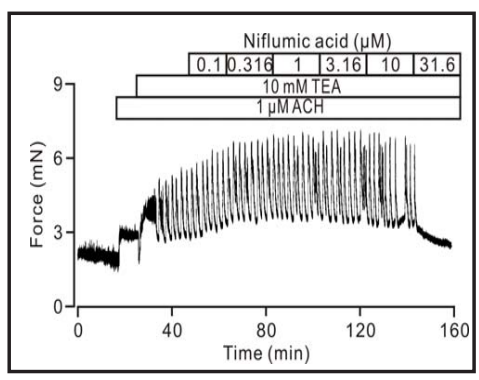

Fig. 5. NCX inhibition abolishes oscillatory contractions. T E A - ind u ced oscillatory contractions in a TR were transiently enhanced and then disappeared following substitution of $\mathrm{Na}^{+}$with $\mathrm{Li}^{+}$(A) and the addition of selective NCX blocker KBR7943 (B).

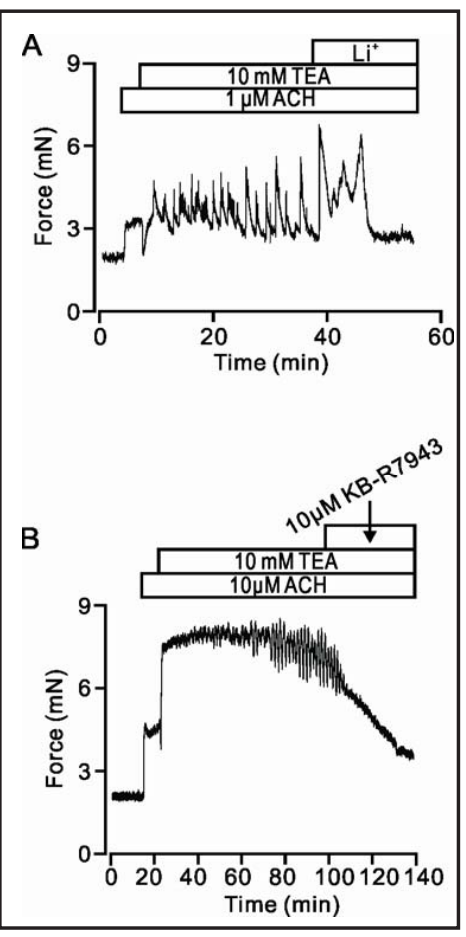

Fig. 6. Ouabain blocks oscillatory contractions. Ouabain induced a transient contraction and then abolished the TEA-induced oscillatory contractions in a TR.

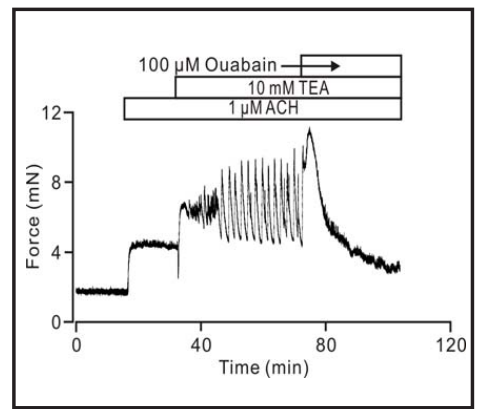


Fig. 7. TEA induces $\mathrm{Ca}^{2+}$ oscillations in ASMCs cells. (A) ACH induced an increase in $\mathrm{Ca}^{2+}$ concentration in ASM cells, and TEA then induced fast oscillations. In addition, a low-frequency rhythmicity was observed as indicated by the dashed line. (B) Comparison of the frequency of the oscillatory contractions and the rhythmicity. ${ }^{* * *}$ : $\mathrm{P}<0.01$.

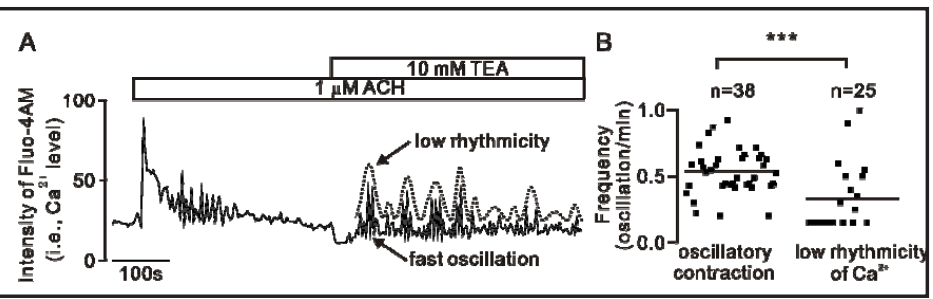

Fig. 8. Effect of intracellular $\mathrm{Ca}^{2+}$ store release and $\mathrm{Ca}^{2+}$ influx on the TEA-induced oscillatory contractions. (A) The incubation of TG abolished TEA-induced oscillatory contractions. (B) Oscillatory contractions were blocked by 2-APB, (C) but not by ryanodine. (D) Oscillatory contractions were abolished following the removal of the external $\mathrm{Ca}^{2+}$.

were abrogated by 2-APB, a blocker of $\mathrm{IP}_{3}$ Rs (Fig. 8B, $\mathrm{n}$ $=6$ ) but not by ryanodine, a selective blocker of RyRs (Fig. $8 \mathrm{C}, \mathrm{n}=6$ ). In addition, the oscillatory contractions were inhibited by the removal of
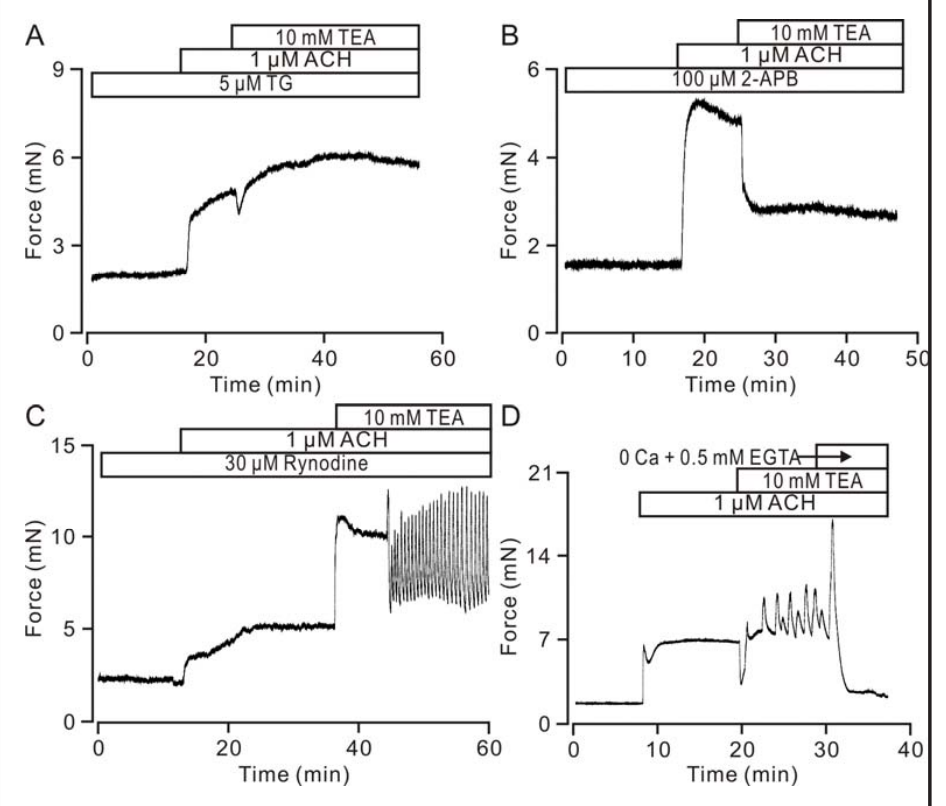
extracellular $\mathrm{Ca}^{2+}$ (Fig. 8D, $\mathrm{n}=$ 4). These results suggest that $\mathrm{IP}_{3} \mathrm{Rs}$-mediated $\mathrm{Ca}^{2+}$ release and external $\mathrm{Ca}^{2+}$ influx (mediated by LVDCCs) are required for oscillatory contractions.

\section{Discussion}

In this study, we have shown that TEA induced oscillatory contractions in resting and precontracted mouse tracheal ASM. In addition, TEA induced fast $\mathrm{Ca}^{2+}$ oscillations in the presence of $\mathrm{ACH}$, as well as another rhythmicity. The frequency of the rhythmicity was close to that of the oscillatory contractions, but was significantly lower than the fast $\mathrm{Ca}^{2+}$ oscillations in the presence of ACH. This suggests that the oscillatory contractions may be triggered by the rhythmicity of cytosolic $\mathrm{Ca}^{2+}$ and some single fast $\mathrm{Ca}^{2+}$ oscillations. Moreover, the oscillatory contractions were inhibited by nifedipine, TTX, niflumic acid, oubain, KBR7943, TG, 2-APB, the replacement of $\mathrm{Na}^{+}$with $\mathrm{Li}^{+}$, and the removal of external $\mathrm{Ca}^{2+}$, but not by ryanodine. These results suggest that oscillatory contractions are coordinately produced by LVDCCs, $\mathrm{V}_{\mathrm{Na}}$ channels, Clca channels, $\mathrm{Na}^{+}, \mathrm{K}^{+}$-ATPase, NCX, intracellular $\mathrm{Ca}^{2+}$ release mediated by $\mathrm{IP}_{3} \mathrm{Rs}$ and extracellular $\mathrm{Ca}^{2+}$ through changing the level of cytosolic $\mathrm{Ca}^{2+}$.

\section{Mechanism of the contractile phase of the oscillatory contractions}

The aim of this study was to investigate the mechanism underlying and the role

of the oscillatory contractions. We hypothesized that one oscillatory contraction would be produced by an increase then decrease of cytosolic $\mathrm{Ca}^{2+}$. Since TEA blocks $\mathrm{K}^{+}$ 
channels, resulting in a contraction through the pathway: $\mathrm{K}^{+}$efflux termination; membrane depolarization; LVDCC activation; and $\mathrm{Ca}^{2+}$ influx. This process was evidenced by the fact that nifedipine abolished the oscillatory contractions (Fig. 3A). Thus, in this study, TEA induced oscillatory contractions regardless of the presence of ACH (Figs. 1A, 2). Such a role of LVDCCs in the oscillatory contractions has been reported previously $[44,45]$. In addition, the LVDCCsmediated contraction will be enhanced by depolarization caused by $\mathrm{V}_{\mathrm{Na}}$ channels-mediated $\mathrm{Na}^{+}$influx. Therefore, following $\mathrm{V}_{\mathrm{Na}}$ channel inhibition by TTX, the oscillatory contractions disappeared (Fig. 3B).

LVDCCs-mediated $\mathrm{Ca}^{2+}$ influx will result in increases in cytosolic $\mathrm{Ca}^{2+}$ concentration, which will activate Clca channels. The Clca channels mediate $\mathrm{Cl}^{-}$efflux, resulting in membrane depolarization that leads to activation of LVDCCs to enhance contraction. This was confirmed by the finding that $\mathrm{Cl}^{-}$channel blocker niflumic acid inhibited the oscillatory contractions (Fig. 4). Consistent with this, knockout of TMEM16A, a Clca channel [46, 47], reduced the oscillatory contractions in mouse stomach smooth muscle [48]. Taken together, the contractile phase of the oscillatory contractions was produced by LVDCCs, $\mathrm{V}_{\mathrm{Na}}$ channels and Clca channels.

In addition, the TEA-induced oscillatory contractions would be affected by $\mathrm{Ca}^{2+}$ release from the ER. This was confirmed by the finding that TEA failed to induce the oscillatory contractions following depletion of intracellular $\mathrm{Ca}^{2+}$ stores with TG (Fig. 8A). Thus, the released $\mathrm{Ca}^{2+}$ would have a role in producing the contractile phase of the oscillatory contractions. Furthermore, we found that 2-APB (Fig. 8B), but not ryanodine (Fig. 8C), abolished the oscillatory contractions. These data suggest that the release was mediated by $\mathrm{IP}_{3} \mathrm{Rs}$, but not by RyRs. However, previous results indicate that both $\mathrm{IP}_{3} \mathrm{Rs}$ and RyRs play a role in the oscillatory contractions in guinea pig ASM [18]. Furthermore, in artery smooth muscle, the TEA-induced oscillatory contractions might not be modulated by the intracellular $\mathrm{Ca}^{2+}$ store and RyRs [49]. These discrepancies may be due to species differences, the agents used to induce the oscillatory contractions, and the state of the muscle (i.e., resting or precontracted).

$\mathrm{Ca}^{2+}$ release and LVDCCs-mediated $\mathrm{Ca}^{2+}$ influx will need extracellular $\mathrm{Ca}^{2+}$. Indeed, this was confirmed by the observation that the oscillatory contractions disappeared following the removal of $\mathrm{Ca}^{2+}$ from the bath (Fig. 8D).

Taken together, our results suggest that the contractile phase of oscillatory contractions depends on LVDCCs-mediated $\mathrm{Ca}^{2+}$ influx, $\mathrm{V}_{\mathrm{Na}}$ channels-mediated $\mathrm{Na}^{+}$entry, $\mathrm{Cl}_{\mathrm{Ca}}$ channelsmediated $\mathrm{Cl}^{-}$efflux, $\mathrm{IP}_{3} \mathrm{Rs}$-mediated $\mathrm{Ca}^{2+}$ release.

\section{Mechanism of the relaxant phase of the oscillatory contractions}

The above pathways-induced $\mathrm{Ca}^{2+}$ increases will activate NCX, which then transfers 1 $\mathrm{Ca}^{2+}$ ion to the extracellular space from the cytoplasm in exchange for $3 \mathrm{Na}^{+}$ions into the cytoplasm, leading to a decrease in cytosolic $\mathrm{Ca}^{2+}$ to cause relaxation. This was confirmed by the finding that the replacement of $\mathrm{Na}^{+}$with $\mathrm{Li}^{+}$induced a transient enhancement of the oscillatory contractions (Fig. 5A). Moreover, the oscillatory contractions were inhibited by NCX inhibitor (Fig. 5B). Thus, NCX contributes to the relaxant phase of the oscillatory contractions.

Meanwhile, NCX will transfer $\mathrm{Na}^{+}$into cells, which, together with that mediated by $\mathrm{V}_{\mathrm{Na}}$ channels, will activate $\mathrm{Na}^{+} / \mathrm{K}^{+}$-ATPase to remove $3 \mathrm{Na}^{+}$ions from and transfer $2 \mathrm{~K}^{+}$ions into the cytoplasm. Thus, the result is hypopolarization, which will then cause inactivation of LVDCCs, leading to relaxation. This was supported by the observation that ouabain, an inhibitor of $\mathrm{Na}^{+} / \mathrm{K}^{+}$-ATPase, first induced a transient contraction and then abolished the oscillatory contractions (Fig. 6). However, it was previous shown that ouabain induced oscillatory contractions in uterine muscle in a concentration-dependent manner [50]. This discrepancy might be due to the different the muscle types.

Overall, the relaxant phase of the oscillatory contractions is induced by NCX-mediated $\mathrm{Ca}^{2+}$ efflux and $\mathrm{Na}^{+} / \mathrm{K}^{+}$-ATPase-induced hypopolarization. 


\section{Cellular Physiology Cell Physiol Biochem 2018;47:1546-1555

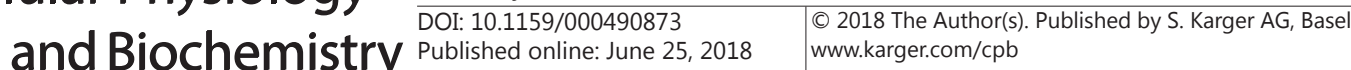 \\ Xu et al.: Oscillatory Contractions in Airway Smooth Muscle}

\section{Mechanism of the regeneration of oscillatory contractions}

How dose the next cycle start? It could be hypothesized that the $\mathrm{Na}^{+}$entry mediated by $\mathrm{V}_{\mathrm{Na}}$ channels and NCX will be larger than that removed from the cytoplasm by $\mathrm{Na}^{+} / \mathrm{K}^{+}-$ ATPase alone. This will lead to a gradual depolarization, which activate LVDCCs inducing a contraction again. This would explain the regeneration of the oscillatory contractions. In addition, $\mathrm{IP}_{3}$ Rs have been suggested to play a role in the regeneration [51].

\section{Potential role of the oscillatory contractions}

What is the role of the oscillatory contractions? It has been suggested that the $\mathrm{Ca}^{2+}$ oscillations induce a sustained contraction of ASM [14, 16, 23, 25-28, 32, 33]. Our results showed not only the same fast $\mathrm{Ca}^{2+}$ oscillations but also a slow rhythmicity (Fig. 7). We speculated that the slow rhythmicity might underlie the TEA-induced oscillatory contractions, based on the finding that the frequency of the rhythmicity was close to that of the oscillatory contractions. However, our results indicate that the former was significantly lower than the latter. We reasoned that each cycle of rhythmicity would trigger one oscillatory contraction. The remaining contractions would be evoked by single larger $\mathrm{Ca}^{2+}$ oscillations.

In summary, our results indicate that TEA induces two types of $\mathrm{Ca}^{2+}$ changes: high frequency oscillation and low-frequency rhythmicity. All of the low-frequency rhythmicities would trigger one contraction and some of the high-frequency oscillations could also respectively trigger a contraction. Thus, the oscillatory contractions persisted. Moreover, the contractile phase of the oscillatory contractions would be induced by LVDCCs, $\mathrm{V}_{\mathrm{Na}}$ channels, $\mathrm{Cl}_{\mathrm{Ca}}$ channels and IP ${ }_{3} \mathrm{Rs}$; the relaxant phase would be induced by NCX and $\mathrm{Na}^{+} / \mathrm{K}^{+}$-ATPase; the regeneration of the oscillatory contractions would be dependent on $\mathrm{V}_{\mathrm{Na}}$ channels, NCX and $\mathrm{Na}^{+} / \mathrm{K}^{+}$-ATPase.

\section{Acknowledgements}

The authors thank Hai-Xia Cheng for the technical assistances. This work was supported by the National Natural Science Foundation of China (31571200, 31140087, 30971514 to Qing-Hua Liu; 31070744 to Ping Zhao), the Open Foundation of Hubei Provincial Key Laboratory for Protection and Application of Special Plants in Wuling Area of China and the Fundamental Research Funds for the Central Universities, South-Central University for Nationalities (CZW15012, CZW15025, CZP17048 to Qing-Hua Liu; CZR18003 to Ping Zhao).

\section{Disclosure Statement}

All authors declare that they have no conflict of interests pertaining to this study.

\section{References}

1 Shen X, Wu MF, Tepper RS, Gunst SJ: Mechanisms for the mechanical response of airway smooth muscle to length oscillation. J Appl Physiol (1985) 1997;83:731-738.

-2 Wang L, Pare PD, Seow CY: Effects of length oscillation on the subsequent force development in swine tracheal smooth muscle. J Appl Physiol (1985) 2000;88:2246-2250.

$>3$ Al-Jumaily AM, Mbikou P, Redey PR: Effect of length oscillations on airway smooth muscle reactivity and cross-bridge cycling. Am J Physiol Lung Cell Mol Physiol 2012;303:L286-294.

4 Shen X, Wu MF, Tepper RS, Gunst SJ: Pharmacological modulation of the mechanical response of airway smooth muscle to length oscillation. J Appl Physiol (1985) 1997;83:739-745.

5 Fredberg JJ, Inouye D, Miller B, Nathan M, Jafari S, Raboudi SH, Butler JP, Shore SA: Airway smooth muscle, tidal stretches, and dynamically determined contractile states. Am J Respir Crit Care Med 1997;156:17521759.

-6 Fredberg JJ, Inouye DS, Mijailovich SM, Butler JP: Perturbed equilibrium of myosin binding in airway smooth muscle and its implications in bronchospasm. Am J Respir Crit Care Med 1999;159:959-967.

7 Jo-Avila M, Al-Jumaily AM, Lu J: Relaxant effect of superimposed length oscillation on sensitized airway smooth muscle. Am J Physiol Lung Cell Mol Physiol 2015;308:L479-484. 


\section{Cellular Physiology Cell Physiol Biochem 2018;47:1546-1555 \begin{tabular}{l|l} 
and Biochemistry Published online: June 25, 2018 & $\begin{array}{l}\text { (c) } 2018 \text { The Author(s). Published by S. Karger AG, Basel } \\
\text { www.karger.com/cpb }\end{array}$
\end{tabular} \\ Xu et al.: Oscillatory Contractions in Airway Smooth Muscle}

8 Al-Jumaily AM, Roos K, Bessaguet S, Jo Avila M: Prestretched airway smooth muscle response to length oscillation. Physiol Rep 2017;5:e13076

-9 Rosner SR, Pascoe CD, Blankman E, Jensen CC, Krishnan R, James AL, Elliot JG, Green FH, Liu JC, Seow CY, Park JA, Beckerle MC, Pare PD, Fredberg JJ, Smith MA: The actin regulator zyxin reinforces airway smooth muscle and accumulates in airways of fatal asthmatics. PLoS One 2017;12:e0171728.

10 Noble PB, McFawn PK, Mitchell HW: Intraluminal pressure oscillation enhances subsequent airway contraction in isolated bronchial segments. J Appl Physiol (1985) 2004;96:1161-1165.

11 Pandya HC, Innes J, Hodge R, Bustani P, Silverman M, Kotecha S: Spontaneous contraction of pseudoglandular-stage human airspaces is associated with the presence of smooth muscle-alpha-actin and smooth muscle-specific myosin heavy chain in recently differentiated fetal human airway smooth muscle. Biol Neonate 2006;89:211-219.

-12 Janssen LJ, Nana R: Na+/k+ atpase mediates rhythmic spontaneous relaxations in canine airway smooth muscle. Respir Physiol 1997;108:187-194.

13 Despa S, Lingrel JB, Bers DM: $\mathrm{Na}(+) / \mathrm{k})+$ )-atpase alpha2-isoform preferentially modulates ca2(+) transients and sarcoplasmic reticulum ca2(+) release in cardiac myocytes. Cardiovasc Res 2012;95:480-486.

14 Perez-Zoghbi JF, Bai Y, Sanderson MJ: Nitric oxide induces airway smooth muscle cell relaxation by decreasing the frequency of agonist-induced ca2+ oscillations. J Gen Physiol 2010;135:247-259.

15 Kirkpatrick CT: Excitation and contraction in bovine tracheal smooth muscle. J Physiol 1975;244:263-281.

16 Mitchell HW: Electromechanical effects of tetraethylammonium and k+ on histamine-induced contraction in pig isolated tracheal smooth muscle. Lung 1987;165:129-142.

17 Yagi Y, Kuwahara M, Tsubone H: Chtx induces oscillatory contraction in guinea pig trachea: Role of cyclooxygenase-2 and pge2 Am J Physiol Lung Cell Mol Physiol 2003;284:L1045-1054.

18 Yagi Y, Kuwahara M, Tsubone H: Ca2+-activated k+ channel blockers induce pkc modulated oscillatory contractions in guinea pig trachea. Comp Biochem Physiol C Toxicol Pharmacol 2002;131:511-519.

19 Sena CM, Santos RM, Boarder MR, Rosario LM: Regulation of ca2+ influx by a protein kinase c activator in chromaffin cells: Differential role of p/q- and l-type ca2+ channels. Eur J Pharmacol 1999;366:281-292.

20 Nicola C, Timoshenko AV, Dixon SJ, Lala PK, Chakraborty C: Ep1 receptor-mediated migration of the first trimester human extravillous trophoblast: The role of intracellular calcium and calpain. J Clin Endocrinol Metab 2005;90:4736-4746.

-21 Roux E, Guibert C, Savineau JP, Marthan R: [ca2+]i oscillations induced by muscarinic stimulation in airway smooth muscle cells: Receptor subtypes and correlation with the mechanical activity. Br J Pharmacol 1997;120:1294-1301.

22 Prakash YS, van der Heijden HF, Kannan MS, Sieck GC: Effects of salbutamol on intracellular calcium oscillations in porcine airway smooth muscle. J Appl Physiol (1985) 1997;82:1836-1843.

23 Bergner A, Sanderson MJ: Atp stimulates ca2+ oscillations and contraction in airway smooth muscle cells of mouse lung slices. Am J Physiol Lung Cell Mol Physiol 2002;283:L1271-1279.

24 Brumen M, Fajmut A, Dobovisek A, Roux E: Mathematical modelling of ca(2+) oscillations in airway smooth muscle cells. J Biol Phys 2005;31:515-524.

-25 Perez JF, Sanderson MJ: The frequency of calcium oscillations induced by 5-ht, ach, and kcl determine the contraction of smooth muscle cells of intrapulmonary bronchioles. J Gen Physiol 2005;125:535-553.

26 Bai Y, Sanderson MJ: Airway smooth muscle relaxation results from a reduction in the frequency of ca2+ oscillations induced by a camp-mediated inhibition of the ip3 receptor. Respir Res 2006;7:34.

27 Ressmeyer AR, Bai Y, Delmotte P, Uy KF, Thistlethwaite P, Fraire A, Sato O, Ikebe M, Sanderson MJ: Human airway contraction and formoterol-induced relaxation is determined by ca2+ oscillations and ca2+ sensitivity. Am J Respir Cell Mol Biol 2010;43:179-191.

-28 Jiang H, Abel PW, Toews ML, Deng C, Casale TB, Xie Y, Tu Y: Phosphoinositide 3-kinase gamma regulates airway smooth muscle contraction by modulating calcium oscillations. J Pharmacol Exp Ther 2010;334:703-709.

29 Wang IY, Bai Y, Sanderson MJ, Sneyd J: A mathematical analysis of agonist- and kcl-induced ca(2+) oscillations in mouse airway smooth muscle cells. Biophys J 2010;98:1170-1181.

-30 Matsumoto H, Hirata Y, Otsuka K, Iwata T, Inazumi A, Niimi A, Ito I, Ogawa E, Muro S, Sakai H, Chin K, Oku Y, Mishima M: Interleukin-13 enhanced ca2+ oscillations in airway smooth muscle cells. Cytokine 2012;57:19-24. 


\section{Cellular Physiology Cell Physiol Biochem 2018;47:1546-1555

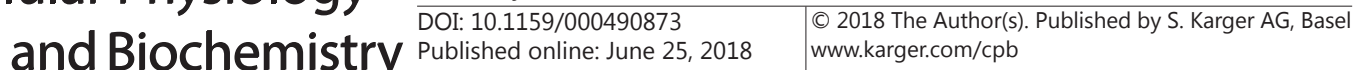 \\ Xu et al.: Oscillatory Contractions in Airway Smooth Muscle}

-31 Mukherjee S, Trice J, Shinde P, Willis RE, Pressley TA, Perez-Zoghbi JF: Ca2+ oscillations, ca2+ sensitization, and contraction activated by protein kinase $\mathrm{c}$ in small airway smooth muscle. J Gen Physiol 2013;141:165178.

-32 Tan X, Sanderson MJ: Bitter tasting compounds dilate airways by inhibiting airway smooth muscle calcium oscillations and calcium sensitivity. Br J Pharmacol 2014;171:646-662.

-33 Chen J, Sanderson MJ: Store-operated calcium entry is required for sustained contraction and ca2+ oscillations of airway smooth muscle. J Physiol 2017;595:3203-3218.

34 Boie S, Chen J, Sanderson MJ, Sneyd J: The relative contributions of store-operated and voltage-gated ca2+ channels to the control of ca2+ oscillations in airway smooth muscle. J Physiol 2017;595:3129-3141.

-35 Zhang T, Luo XJ, Sai WB, Yu MF, Li WE, Ma YF, Chen W, Zhai K, Qin G, Guo D, Zheng YM, Wang YX, Shen JH, Ji G, Liu QH: Non-selective cation channels mediate chloroquine-induced relaxation in precontracted mouse airway smooth muscle. PLoS One 2014;9:e101578.

-36 Wei MY, Xue L, Tan L, Sai WB, Liu XC, Jiang QJ, Shen J, Peng YB, Zhao P, Yu MF, Chen W, Ma LQ Zhai K, Zou C, Guo D, Qin G, Zheng YM, Wang YX, Ji G, Liu QH: Involvement of large-conductance ca2+-activated k+ channels in chloroquine-induced force alterations in pre-contracted airway smooth muscle. PLoS One 2015;10:e0121566.

-37 Jiang QJ, Chen W, Dan H, Tan L, Zhu H, Yang G, Shen J, Peng YB, Zhao P, Xue L, Yu MF, Ma L, Si XT, Wang Z, Dai J, Qin G, Zou C, Liu QH: Cortex phellodendri extract relaxes airway smooth muscle. Evid Based Complement Alternat Med 2016;2016:8703239.

-38 Liu QH, Zheng YM, Korde AS, Yadav VR, Rathore R, Wess J, Wang YX: Membrane depolarization causes a direct activation of g protein-coupled receptors leading to local ca2+ release in smooth muscle. Proc Natl Acad Sci U S A 2009;106:11418-11423.

-39 Yim PD, Gallos G, Perez-Zoghbi JF, Trice J, Zhang Y, Siviski M, Sonett J, Emala CW, Sr.: Chloride channel blockers promote relaxation of tea-induced contraction in airway smooth muscle. J Smooth Muscle Res 2013;49:112-124.

40 Snetkov VA, Hirst SJ, Ward JP: Ion channels in freshly isolated and cultured human bronchial smooth muscle cells. Exp Physiol 1996;81:791-804.

41 Sathish V, Delmotte PF, Thompson MA, Pabelick CM, Sieck GC, Prakash YS: Sodium-calcium exchange in intracellular calcium handling of human airway smooth muscle. PLoS One 2011;6:e23662.

42 Shattock MJ, Ottolia M, Bers DM, Blaustein MP, Boguslavskyi A, Bossuyt J, Bridge JH, Chen-Izu Y, Clancy CE, Edwards A, Goldhaber J, Kaplan J, Lingrel JB, Pavlovic D, Philipson K, Sipido KR, Xie ZJ: Na+/ca2+ exchange and na+/k+-atpase in the heart. J Physiol 2015;593:1361-1382.

43 Efendiev R, Bertorello AM, Zandomeni R, Cinelli AR, Pedemonte CH: Agonist-dependent regulation of renal na+,k+-atpase activity is modulated by intracellular sodium concentration. J Biol Chem 2002;277:1148911496.

44 Wu L, Wang Z, Wang R: Tetraethylammonium-evoked oscillatory contractions of rat tail artery: A k-k model. Can J Physiol Pharmacol 2000;78:696-707.

45 Kamouchi M, Kitazono T, Nagao T, Fujishima M, Ibayashi S: Role of ca(2+)-activated k+ channels in the regulation of basilar arterial tone in spontaneously hypertensive rats. Clin Exp Pharmacol Physiol 2002;29:575-581.

46 Schroeder BC, Cheng T, Jan YN, Jan LY: Expression cloning of tmem16a as a calcium-activated chloride channel subunit. Cell 2008;134:1019-1029.

-47 Caputo A, Caci E, Ferrera L, Pedemonte N, Barsanti C, Sondo E, Pfeffer U, Ravazzolo R, Zegarra-Moran O, Galietta LJ: Tmem16a, a membrane protein associated with calcium-dependent chloride channel activity. Science 2008;322:590-594.

48 Huang F, Rock JR, Harfe BD, Cheng T, Huang X, Jan YN, Jan LY: Studies on expression and function of the tmem16a calcium-activated chloride channel. Proc Natl Acad Sci U S A 2009;106:21413-21418.

49 Tostes RC, Storm DS, Chi DH, Webb RC: Intracellular calcium stores and oscillatory contractions in arteries from genetically hypertensive rats. Hypertens Res 1996;19:103-111.

50 Tsai ML, Chang CC, Lee CL, Huang BY: The differential effects of tamoxifen and ici 182, 780 on the reduction of na+/k+ atpase activity and spontaneous oscillations by 17beta-estradiol. Chin J Physiol 2003;46:55-62.

51 Lee CH, Poburko D, Kuo KH, Seow CY, van Breemen C: Ca(2+) oscillations, gradients, and homeostasis in vascular smooth muscle. Am J Physiol Heart Circ Physiol 2002;282:H1571-1583. 